\title{
Sexual Orientation in Portugal: Towards Emancipation
}

\author{
ANA CRISTINA SANTOS
}

In a context of hegemonic globalization, minorities constitute counterpowers whose potential for resistance and subversion may effectively result in a renegotiation of the rules of the game. In this context, the complex, heterogeneous and often diffuse lesbian-gay-bisexualtranssexual movement (LGBT) ${ }^{1}$ offers an important challenge to contemporary sociological thought (Stein and Plummer 1996; Hawkes 1996; Seidman 1997). There are two central aspects to the debate about the LGBT movement within the wider reflection upon alternative forms of social emancipation. First, there is voluminous historical evidence of the oppression of homosexual, bisexual and transsexual men and women throughout the centuries by the 'compulsive heterosexuality' (Rich 1993) and, since the Inquisition, there have been many cases of persecution, torture and murder of people because of their sexual orientation, acts still legally permitted in some countries (Mott 1987; Richards 1990; Amnesty International 1997; and Rosenbloom 1996). But, rather than simply repeat well-known facts, there is a need to question whether this form of oppression necessarily contains potential for emancipation. In other words, is the social oppression of a particular minority group enough to turn it into a counterhegemonic force?

The second important aspect is the so-called 'pink industry', which, since the 1980s has become a visibly lucrative trade, resulting in the design and production of cultural products specifically targeted towards this sector of the market. It includes its own press, bars, discotheques, saunas, hotels, sex shops, among others, as well as the growth of

The author would like to thank Boaventura de Sousa Santos and João Arriscado Nunes for their constructive criticism of the various versions of this essay. Thanks also to Fernando Fontes and Sílvia Ferreira for their careful reading of the text, constant availability and comments, and to the authors of the other essays in this volume with whom I had the privilege of working during the Symposium 'The Reinvention of Social Emancipation', held in Coimbra from 23 to 26 November 2000. 
the international gay tourist circuit. The expansion of this specifically gay market has been largely due to the forces of globalization, which have made available a wide range of 'pink' products for consumption by male homosexuals. Factors such as an allegedly better social and economic status, and successful publicity campaigns specifically directed at the gay consumer, have obviously played an important part. Lastly, the growing public visibility of homosexuality, evident in the frequency of debates and demonstrations, for example, reflects the benefits that the LGBT movement has reaped from globalization, particularly by means of electronic information networks and tourism.

This essay is divided into four sections. It begins with a theoretical reflection on the concepts of equality and difference, leading to the question of the conditions and possibilities provided by capitalism to the struggle for sexual emancipation. This is followed by an analysis of the specific nature of contemporary Portuguese society, considering questions such as its semiperipheral location, the fragility of civil society and the predominance of Judaeo-Christian ethics. Then, I will move to a more empiricial reflection on the strategies, alliances and socio-political aims of the Portuguese LGBT organizations, within the international context of the globalization of the LGBT movement. This involves the examination of documents, internal literature, and other theoretical and empirical studies on this subject, with priority given to the direct observation of recent public events organized by this movement such as the Gay Pride March (June 2000), the Gay Pride Fest (Arraial Gay) (1999 and 2000), and the Gay and Lesbian Film Festival (1999 and 2000). Finally, I will attempt to assess the counterhegemonic potential of the struggle for sexual emancipation, based on the involvement of the Portuguese LGBT movement in other struggles for the right to difference and non-discrimination.

\section{CONSTRUCTING EQUALITY AND DIFFERENCE}

The systems of inequality and exclusion surrounding us and affecting our daily lives result from a complex interplay of powers, by means of which hegemonic groups construct and impose languages, ideologies and beliefs which lead to the rejection, marginalization, or silencing of all who oppose them. This is a historical process of hierarchization, according to which a culture, by means of a discourse of truth, creates proscriptions and thus defines the boundary beyond which all is transgression. With these rules, all groups affected by social proscriptions (such as the insane, criminals, gypsies, homosexuals, etc.) are pushed into the margin of the heterotopia (Santos 1999). In speaking of equality and difference, we are necessarily conditioned by a context that is by no means neutral. 
The right to difference is not the same as equal rights for all. The right to difference means that specific characteristics are not devalued, and that there are alternatives that do not lead to scapegoating. It means the rigorous application of a categorical imperative that could be phrased thus: the right to be equal whenever difference makes us inferior; the right to be different whenever equality decharacterizes us (Santos 1999: 45). Therefore, I propose the concept of 'useful universalism' to define a politics involving the diffusion of universal principles of nondiscrimination while retaining the constitutive aspects of the identity of subcultures valued by the individuals involved. Thus, it becomes possible to defend the general application of laws and, simultaneously, the legal protection of groups likely to be excluded. This seems to have been the double concern of the Portuguese state when, on 15 March 2001, its Parliament approved bills on so-called joint or common economies (law 6/2001, of 11 May) and common-law partnerships (law 7/2001 of 11 May), irrespective of gender. The passing of both bills made clear the need for positive discrimination for homosexual citizens. For, while there is nothing that prevents a homosexual couple from benefiting from the legal protection provided by the law on common economies, this was considered insufficient by Portuguese LGBT associations, since it removes the affective component from the LGBT family relationship, reducing it to a merely economic concern. ${ }^{2}$ This was why, during the street demonstration in front of the Sixth Civil Registry Office on 6 February 2000, several lesbian and gay couples kissed each other while waving placards bearing the words 'This is common economy!' By explicitly stipulating in Article 1 that it applies to 'any two people, regardless of gender', the law on common-law partnerships thus provides against narrower interpretations of the protection in question.

Thus, it may be concluded that the route to a more inclusive society passes through stages in which it is neither useful nor just to promote an essentialist universalism that does not take into account the specifics of the context. Useful universalism should lead to policies of equality, while avoiding homogenization, which is always carried out by those at the top of the pyramid. It is because of this risk of homogenization that some LGBT activists have strongly criticized the discourse of equality, arguing that 'equal rights' ultimately aim at the annulment of diversity within the LGBT movement itself. In fact, recognition of the rights of LGBT couples may be interpreted as an incentive or reward for adhering to a model of sexual behaviour very close to that of conventional heterosexuality, namely a stable, monogamous relationship ${ }^{3}$ (Tatchell 2001).

Reflection upon equality and difference should be viewed within the context of neoliberalism, where these poles intersect, approximate and 
diverge, forming complex dynamic networks that are not always easy to disentangle. The relation between the Portuguese LGBT movement and the capitalist system is permeated by contradictions that derive from this complexity as well as from the need to constantly articulate the resources available to groups which, while struggling for equal rights, wave the banner of pride in difference.

The following is a brief analysis of the conditions imposed by the dominant system on the struggle for sexual emancipation, in an attempt to understand the extent to which this may be successful in the context of a capitalist society.

\section{(In)Equality in the Capitalist System}

Clearly, situations of extreme poverty, involving a constant struggle for survival, do not leave much space, or energy, to the struggle for other causes apparently less crucial. However, when objective conditions of existence improve, then the spectrum of social claims and complaints broadens, since it is at this point that other needs, such as freedom of expression or of self-determination of the body, become visible. It is in this sense that the capitalist system has provided some of the essential conditions for the emergence of the homosexual movement, amongst which the most important are the monthly salary and the manufacture of products for consumption.

In a frequently quoted article, D'Emilio (1996) argues that:

It has been the historical development of capitalism - more specifically, its free-labor system - that has allowed large numbers of men and women in the late twentieth century to call themselves gay, to see themselves as part of a community of similar men and women, and to organize politically on the basis of that identity (1996:264).

In fact, by removing from the family unit its traditional role of economic producer, the capitalist system converted it into a space for the establishment and strengthening of affective relations, which would permit the worker to maintain the high level of performance required by the system. What was unexpected in this process was that the nuclear family was transformed into a space for well-being and happiness where feelings were given priority over obligations. Thus, the way was opened for new family models which transcend traditional blood ties. On 24 March 2000, a paper presented by ILGA-Portugal at the Alternative Summit defined the family for the LGBT organization as follows:

Many of us are in common-law partnerships, therefore we are in favour of the family, understood as the privileged place for 
affections, and not as a legal transaction. For us, the family is not only the old family that we have inherited, which in many cases is in grave crisis, but also our new families, involving same-sex couples, single mothers, lesbian mothers, single fathers, widows and widowers, gays, bisexuals, transsexuals, families with adopted children, and with children resulting from artificial insemination, all who feel themselves to be in a family in the home where they are brought up, cared for, looked after and loved (Rodrigues 2000).

This transformation has affected the heterosexual family itself. The number of children per couple, for example, has dropped dramatically, now that children are no longer needed as workers contributing to the household economy, but are instead desired for affective reasons.

Furthermore, the development of markets has led to a greater circulation of people and goods, which stimulates an exchange of information and experience that would otherwize have remained unknown. António Serzedelo, president of Opus Gay, argues that policies for economic growth:

have given Portugal good roads and bridges, which bring things into the country - or don't, but that is another question - and these roads have also brought into the country many European ideas dear to the urban bourgeoisie. A side-effect, certainly not anticipated, is that with this have come, on aeroplanes, buses and trains, liberalizing ideas which are the consequence of the liberalization of capital (Santos and Fontes 1999).

In fact, the decade of the 1990s saw the beginning of a Portuguese LGBT market, consisting mostly of night spots, such as bars and discotheques, but also including saunas, an estate agency, a hotel, a travel agency, a bookshop and the magazine Korpus (the only gay periodical since 1996), in addition to the different services provided by the associations themselves. Therefore, there seems already to be a perception that homosexuals are also consumers whose purchasing power may be attracted commercially, although in Portugal this market is still a long way from the 'pink' industries of the United States, the United Kingdom or even Spain. In any case, the increasing socio-economic power of this group has led to a greater capacity for the negotiation of social and political rights, as well as to a growth in the public visibility of homosexuality. According to Santos, 'many social groups which are "different", such as ethnic minorities and others, have begun to have 
sufficient organizational resources to enable their specific needs and aspirations to be placed on the political agenda' (1999: 23).

The other side of the coin is that capitalist ideology is at the origin of sexual oppression, an aspect which is considered below. Some studies have identified the bourgeois nuclear family (defined as the economic institutionalization of personal relations in the context of the capitalist system) as the main justification for homophobia. ${ }^{4}$ This oppression dates back to the period when the bourgeois family model began to be instituted, incorporating an 'economically useful and politically conservative sexuality' in the words of Foucault (1994: 41). It was with this family model that the sexual division of labour was introduced, according to which women were responsible for maintaining the stability of the home, taking care of clothes, meals, cleaning and children. Although this role amply served the needs of the economic system, it did not result in social recognition, and women were relegated to routine tasks considered unimportant. This means that, although women had been oppressed and exploited long before this time, the bourgeois nuclear family model contributed to reinforcing the inequalities in which women were caught. Even though the labour market gradually began to absorb women into the work force, after the industrial revolution, the traditional role of women in the home did not change greatly (Ferreira 1981). Indeed, capitalist ideology constructed and disseminated a strong sexual dichotomy which assigns different and frequently opposed roles to men and women (Joaquim 1998; Müller 1998; Osório 2002). Homophobia is one of the facets of this patriarchal ideology, since individuals, whether men or women, who consider themselves equal and fight for the right to difference, constitute a real threat to a system whose construction has been based on dichotomies that also pertain to gender. In other words, the bourgeoisie:

terrified by the communist spectre of the equality of women and men, labels sexual equality as unnatural. Gayness is also labeled 'unnatural' and therefore a threat to bourgeois domination, precisely because it rejects the 'natural' bourgeois society as reflected in the 'natural' bourgeois/proletarian relationship of the nuclear family (LARG 1996: 350).

Even these days, homosexual workers are frequently dismissed or have their career advancement blocked (in slang, to be 'shelved') for motives that have less to do with work performance than with their sexual orientation, inferred or assumed. ${ }^{5}$ Knowledge of this type of discrimination affecting LGBT workers led to the approval of a motion supporting the claims of the Gay, Lesbian and Transvestite Movement at the Sixth 
National Congress of the Brazilian union federation Central Única de Trabalhadores, in São Paulo, in August 1997:

The 6th CONCUT resolves: ... to fight homophobia within trade unions and at the workplace, by developing a policy designed to suppress discrimination against gays, lesbians and transvestite workers in unions and in society at large, in general agreement with entities that are already struggling against this prejudice (CUT 1997: 61).

Outside the sphere of work, whenever a homosexual parent is refused child custody, whenever a LGBT couple avoids affectionate behaviour in public, or whenever a gay is beaten up for not being heterosexual, there is a subjugation of difference to the heterosexual hegemony, which also serves the interests of bourgeois capitalism. The fact that this oppression operates on the basis of sexuality - seen equally in regard to race, class or gender - reveals how powerful the weapons of capitalism are in depriving individuals of their power of resistance, condemning them to isolation and invisibility for the most diverse of reasons.

In addition to these more direct forms of exclusion due to homophobia, the allegedly high economic status of homosexuals is not enough to emancipate them. In a message distributed by e-mail in August 2000, the Australian organization Queers United to Eradicate Economic Rationalism (QUEERS) warned about the false acceptance that homosexuals were apparently enjoying as a distinct market niche, as a result of their spending power. In this message, the group rejected this claim to acceptance, arguing that 'our rightful place in society must not be bought. Freedom does not come from consumption' (QUEERS 2000). This rejection of an LGBT lifestyle characterized by a high level of consumption is at the basis of 'Queeruption', a celebration of alternative gay pride, ostensibly non-commercial and strongly politicized, planned for London and San Francisco, in an attempt to overcome the image of gay identity as 'having less to do with sexual orientation than with the make of beer that you drink, the car you drive or how you decorate your house' (Fox 2001).

The Madrid neighbourhood of Chueca is another example. Although this area is apparently receptive to the LGBT community, where trade and industry have developed with the gay consumer in mind, ${ }^{6}$ the truth is that Chueca is no more than a commercial ghetto, around which a certain LGBT lifestyle has developed. That is to say, it is a community with buying power, which takes care of the body but is diluted, without many concerns for its identity, within a society that continues to be patriarchal and heterosexist. Once again, consumption has not resulted in the actual 
inclusion of gays as citizens, but only in the appropriation of a circumscribed area of the city. One of the greatest risks of 'pink consumption' is the subversion of the emancipatory objectives of LGBT organizations, as Eugeni Rodriguez (2000) of the Gay Liberation Front of Catalonia has pointed out:

The construction of this network effectively ridicules, marginalizes and criminalizes the gay liberation movement ... The union of gay entrepreneurs with politicians, eager to normalize homosexuality, is behind this lobby. The rights of gays no longer require confrontation, but rather their insertion into consumer society and their restriction to specific neighbourhoods and timetables.

In Portugal, Vitorino (2000) has warned of the danger of confusing the role of the associations, as a network for support and integration of LGBT youth, with the role of the commercial establishments, oriented towards entertainment, consumption and maximum profit. ${ }^{7}$ One obvious difference between the two is the fact that a poor homosexual, living in a rural region and terrified at the possibility that his sexual orientation might be socially exposed, is a very different case from one whose economic power allows him to frequent the circuits of gay tourism, participate in private parties or go regularly to the saunas and night bars in the capital.

\section{SPECIFIC LEGAL, SOCIAL AND RELIGIOUS CONDITIONS IN PORTUGAL}

In order to understand the emergence of the LGBT movement in Portugal, it is necessary to contextualize it in space and time, and take into consideration the specific situation resulting from the country's semiperipheral position in the world system. In effect, Portuguese society has some features that are similar to those of core countries, together with others that have more in common with peripheral countries (Santos 1992: 105). Its gradual approximation to the rest of Europe, culminating in its joining the European Union in 1986, has meant an effort to bring the Portuguese legal system up to the level of the constitutions and legal codes of other European countries.

Eight years after the democratic revolution of 1974, the Portuguese Penal Code was revized, in the wake of the policy of approximation to the rest of Europe. Asserting the principle that its task was to protect freedom of determination and the authenticity of sexual expression, and not to control sexual morality, the new penal code decriminalized sexual acts practised by consenting adults in private. These included adultery, incest, 
prostitution and homosexuality, which had figured in previous penal codes (including the reform project of 1966) as 'crimes against decency' or 'crimes against custom'. Only 'sexual crimes' such as rape, indecent assault, public offence to modesty or the assault of minors are now punishable. This is why the new penal code only punishes homosexuality in cases involving children under 16 (Article 207). With the alterations introduced in 1995, homosexual relations with an adolescent between 14 and 16 years of age continue to be punished, a situation which may be contrasted with heterosexual relations in the same circumstances, for which legislation allows the possibility of the minor's informed consent (Articles 174 and 175).

One feature specific to Portugal is the frequent inconsistency between the formal law and its effective application. This affects the way in which sexuality is experienced, permitting the persistence of attitudes and behaviour that are inconsistent with the progressive legal system being asserted. This lack of coherence may operate in different ways: through an excessive time lapse between the approval of the law and its implementation; failure to enforce the law or selective enforcement; and the instrumental use of the law (Santos 1992: $135 \mathrm{ff}.){ }^{8}$

Since the last quarter of the twentieth century, Portuguese civil society has been showing a greater capacity to voice demands, with the emergence and action of many different social movements, the most recent of which is the LGBT movement. However, half a century of dictatorship and the persistence of a strong Catholic morality (which will be analyzed below) have meant that intervention in the public sphere has been meagre and that existing social movements are frail. ${ }^{9}$ Unlike many core countries, Portugal has not had any strong social movements, although there are associations active in the field of women's rights, workers' rights, ${ }^{10}$ the fight against racism, and, more recently, environmental protection. If we relate Portuguese civil society's weak level of intervention with the characteristics of its social basis of support, we can infer that 'the weakness of protest groups is due to the reduced importance of the new middle classes and, consequently, to the fact that the (rural) populations only mobilize when their immediate material interests are at stake' (Rodrigues 1995: 7). ${ }^{11}$

The fragility of civil participation is counterbalanced by moments of strong activism and the mobilization of certain sectors of the population around issues that affect and/or directly threaten their daily lives. That was what happened in 1998 when the country witnessed the sudden appearance of citizen groups, organized in two months, to campaign in the period before the referendum about the decriminalization of 
abortion. ${ }^{12}$ In a country where issues of sexual politics and reproductive rights have no deep-rooted tradition, there was an ardent public debate about sexuality, in which an active part was played by common citizens as well as by experts. This participation around the time of the campaign was not, however, reflected in the percentage of votes at the referendum, which was only 31.94 per cent.

The (lack of) civic participation by the Portuguese in debates or movements about social issues is to a large extent influenced by the stance of the Catholic Church in relation to some of the issues in question. Indeed, the Portugese clergy has shown that it has considerable powers of social intervention, both in blocking initiatives and in mobilizing people, often determining the direction taken by political decisions. Given the central role of religion in Portugal, particularly incisive in questions of sexuality, it is worth taking a closer look at some of the issues raised by this situation.

\section{Catholicism in Portugal}

Portuguese society has been profoundly influenced by Judaean-Christian morality, reinforced by the frequent interventions of the Catholic Church in matters concerning sexuality. In fact, the Portuguese Catholic Church has long played a central role in defining the boundaries between what is socially desirable and what is morally wrong, and it is between these two poles that the game of sexual emancipation is played out. As we shall see, the Catholic Church has blocked both women's emancipation (systematically condemning the use of contraceptives, abortion, and the right of women to enter the priesthood), and the emancipation of LGBT rights (issuing public statements against common-law partnerships between homosexuals).

As regards contraception, in March 1996, a television advertisement prepared by an NGO involved in the struggle against AIDS showed a priest handing a condom to a young couple in front of a church. The Catholic Church reacted violently, by declaring the advertisement to be complete nonsense and in bad taste (Expresso 30 March 1996).

In 1998, concerning the referendum on the decriminalization of abortion, the clergy also clearly influenced the results obtained. On 3 February 1998, following a meeting of the Portuguese Episcopal Council, a pastoral letter was published asserting that in the referendum, Catholics and other citizens should not stray, having a clear duty to declare themselves in favour of life' (Público 21 February 1998). In the week of the referendum, the cathedral of Braga, in the north, displayed two posters with the words: 'With intelligence and conscience, say no to 
abortion' (Praça 1998: 8). Another example, amongst many others, was the strategy followed by the parish of Nossa Senhora de Lourdes in Coimbra, which included in its weekly newsletter articles and comments invariably opposed to decriminalization. In fact, the Church made use of multiple mechanisms to sway the vote against decriminalization of abortion. It was in the light of this potential for social mobilization by the Portuguese Catholic Church that political and social analysts interpreted the results of the referendum, held on 28 June 1988, as representing a clear division between the conservative Catholic North and the secular liberal South (Moreira 1998; Santos 2001).

These examples, based upon the public position of the Catholic Church relative to issues of contraception and abortion, clearly illustrate a profoundly conservative attitude in matters of sexuality, as well as an attempt to maintain a strong power of moral regulation. It is this power which the Catholic Church also seeks to use in the field of sexual orientation. That is why its public interventions on matters of homosexuality usually take place at times when political decisions are being made in respect to LGBT rights in the country. Regarding the power of the Catholic Church to exercise regulation over issues related to sexual orientation in Mexico, Mejía states that:

the Church was the true moral author, through its medieval understanding of homosexuality, of the oppressive environment of the not very distant past ... and of anti-gay prejudice ... The state's written and unwritten rules aimed at safeguarding Mexican morals and public decency were copied from the Church's teachings. (2000: 53)

In Portugal also, religious intervention is partly responsible for the systematic blocking of progressive social and legal efforts, promoting concepts such as sin and normality, diffusing fear, and instigating disapproval and rejection. Among many others, we can cite the following example: in 1994, a national newspaper made a front page story out of the intention by the Socialist Youth to legalize common-law partnerships between homosexuals (Expresso 13 June 1994). This news aroused hard commentaries of a homophobic nature from the then archbishop of Braga, D. Eurico Dias Nogueira:

The state will soon be the first victim, because a state that is not based upon properly constituted families is a fragile state.... The fall of the Roman Empire was not due to barbarian attacks but to the break-up of the family unit (Expresso13 June 1994). 
Some time later, the same archbishop once again stated his opposition to the legalization of common-law partnerships between homosexuals in the same newspaper:

To classify a homosexual union as a family is an abuse, it is nonsense. I do not question the existence of people who have chosen these paths, or their rights; the problem is that they want to call a family something that cannot in any way be considered one (Rodrigues 1994: 19).

In a pastoral letter entitled 'The Church in Democratic Society', published in 2000, the Portuguese Episcopal Council (CEP) openly rejected the 16 March recommendation of the European Parliament to its Member States to extend to single-parent families and common-law partnerships the same rights as enjoyed by married couples. Rejecting any equivalence between the concepts of 'common law partnership' and 'family', the CEP placed itself clearly on the side of the Pontifical Council for the Family, which, in its document 'Family, Matrimony and Common-law Partnerships', dated November 2000, asserted that common-law partnerships between homosexuals 'are a deplorable distortion of what ought to be a communion of love and life between a man and a woman, who are committed to each other and to the generation of life'.

On 26 April 2001, the Portuguese Episcopal Council published a document entitled 'Crisis of Society - Crisis of Civilization', in which it analyzed the legislative recognition extended the previous month by the Portuguese parliament to common law partnerships between people of the same sex, accusing legislators of undermining the 'dignity of the family'. In the opinion of the Portuguese bishops, the approval of the law on common-law partnerships reveals 'the intentions of certain groups to cause ruptures in the structure of traditional Portuguese culture, or even in what concerns the influence of Church doctrine upon society', concluding that cultural change of this kind heralds a crisis of civilization. This public position of the Catholic Church, which was contested by some political and social sectors and praised by others, effectively reaffirmed the Church's power of contestation and intervention on matters of sexual morality.

Comparing the ecclesiastical perspective with the beliefs and attitudes of the Portuguese people, there is evidence of a strong rejection of male and female homosexuality amongst practising Catholics. Although the number of non-believers who accept sexual relations of gays and lesbians is 22.6 per cent and 24.1 per cent respectively, this figure drops to 5.5 per cent amongst practising Catholics and followers of other religions (Pais 1998: 442). Therefore, if we consider that 89 per cent of Portuguese 
people consider themselves to be religious, and that 97 per cent of those are Catholic (Vala et al. 2003), it is clear that Catholic morality exercises a massive influence upon political decisions directly affecting LGBT citizens, and also upon the emergence and consolidation of the LGBT movement in Portugal. It is this process that will be the concern of the next section.

\section{THE EMERGENCE OF THE LGBT MOVEMENT IN PORTUGAL}

The achievement of democracy after the political-military revolution in April 1974 generated a climate of ideological openness, apparently propitious to the acceptance of perspectives that had been silenced for almost half a century by the Salazar regime. Throughout the revolutionary period, there were some manifestations of homosexual mobilization in the country. In 1974, during the 1 May celebrations in Oporto, a placard appeared bearing the words 'Freedom for Homosexuals'. On 13 May of the same year, the Diário de Lisboa published the manifesto of the Revolutionary Homosexual Action Movement (Movimento de Acção Homossexual Revolucionária MAHR), entitled 'Freedom for Sexual Minorities'. ${ }^{13}$ Six years later, on 25 October 1980, the Revolutionary Homosexual Collective (CHOR) was established. Despite the importance of this movement as the first dynamo of collective action for Portuguese homosexuals, CHOR disappeared two years later. During the 1980s, there were two other events that directly affected the Portuguese gay/lesbian scene: first, the cycle of debates 'To Be (Homo)sexual', which took place in 1982 at the National Centre for Culture, considered to be the first large-scale public debate on the theme; then, the First and Second National Congresses of Sexology, held in 1984 and 1987, in which the topic of homosexuality was discussed by a panel.

With the exception of these movements, the 1980s were disappointing for many as regards what was achieved in this area, especially given the situation in countries like Great Britain, France and the United States. ${ }^{14}$ But while this decade was perhaps characterized by a series of small dispersed events, such as debates, the 1990s were marked by the emergence of different LGBT organizations and by various actions organized by them. Therefore, it seems appropriate to describe some of the principal organizations which have been working in the field for more than a decade.

In 1990, the journal Organa was launched by a group of lesbian women with the objective of debating issues related to homosexuality and fighting the isolation of many lesbian women outside the urban centres. 
A year later, the Homosexual Working Group (Grupo de Trabalho Homossexual - GTH) was established within the Revolutionary Socialist Party, with the aim of 'raising the consciousness of Portuguese society as regards the repression and discrimination practised by the dominant sexual morality' (GTH 1991). This group, which presently has 30 members, organizes mostly street demonstrations and other activities to expose attitudes of homophobia, ${ }^{15}$ and has been directly involved in struggles to alter legislation to provide more legal protection against discrimination. The most important of these was the demand for the approval of the law on common-law partnerships between people of the same sex and the inclusion of non-discrimination on the basis of sexual orientation in Article 13 of the Constitution of the Republic where the principle of equality between citizens is defined.

In 1993, Organa was replaced by Lilás, a triannual magazine for the dissemination of information and the defence of lesbian rights, which has gradually become an association, organizing meetings, poetry sessions, discussions about literature and film, and gatherings for collective reflection. One of the main objectives of the Lilás Group has been to distribute information to lesbians in rural parts of the country.

In 1995, the Portuguese delegation of the International Lesbian and Gay Association (ILGA-Portugal) began operations, gaining official recognition in November 1997 with the inauguration of the new Gay and Lesbian Community Centre in a building provided by the Lisbon City Council. This organization has a documentation centre and a bar, provides weekly psychological and legal consultations, and frequently stages plays, poetry sessions or thematic festivals. It is currently the largest lesbigay association in Portugal, both as regards the number of members (estimated betwen 500 and 600), and the amount of initiatives it organizes.

In January 1996, the Sappho Club was formed by three friends, and although it still does not have premises or formal statutes, it now has 100 members and sympathizers, who hold meetings, New Year's Eve parties, sports activities, and an annual Sapphic camp. Since September 1997, it has published the bi-monthly newsletter Zona Livre, for the propagation of information about lesbian issues, with a growing capacity to fight against discrimination.

The magazine Korpus, the first and, until now, only male homosexual periodical, was launched in September 1996 by Isidro Sousa. Covering a wide range of LGBT issues, it has approximately 200 regular subscribers and is sold all over the country.

Opus Gay appeared in 1997, with the aim of working in the area of LGBT human rights. Based in Lisbon since September 1998, this 
organization has 80 members, with informal delegations in Oporto and Coimbra. Amongst its activities, the most important was the commemoration of Gay Pride Day, on 19 June 1999, which took place outside the capital, in Oporto. It has also prepared the first anthology of homoerotic literature in Portuguese, bringing together texts in prose and poetry by Portuguese authors. It also provides a series of services for the LGBT community, including 'dog and cat sitters', a home cleaning service, legal, medical and psychological advice, tarot sessions, and a philately club. It also publishes a monthly newsletter, with useful contacts, forthcoming events, national and foreign news, as well as sections for poems, reading suggestions and personal messages.

In May 1998, the women of ILGA-Portugal formed the Women's Group (Grupo de Mulheres - GM). With its own issues and manifesto, this group has made a mark on the lesbian scene through its organization of debates, lunches, excursions and other entertainments. In 1999, it organized a Cycle of Lesbian Films, shown on Saturdays at the ILGAPortugal headquarters to an audience composed almost exclusively of women. During the preparation of the Third Gay and Lesbian Film Festival, this group played an important part in the selection and subtitling of the films for women.

In May 2000, the group NÓS appeared, a self-designated university movement for sexual freedom, based at the University of Oporto. In a communique, it asserted its aim to 'confront the viewpoints of the hegemonic (heterosexual, homophobic, macho) tradition with all the other existing truths'. It also organized most of the activities of the First LGBT Pride Week in Oporto, in 2001, such as debates, film showings, poetry sessions and awareness campaigns aimed toward the general public.

In September 2000, the Group Gay West was set up by Simão Mateus, with the main aim of including in the LGBT community gays living in the western part of the country. This group organizes discussion sessions about discrimination and homosexuality, and aims to set up spaces where gays can socialize.

Finally, in November 2001, the association 'don't deprive yourself [não te prives] - Group for the Defence of Sexual Rights' appeared in Coimbra. Although it is not an exclusively LGBT association, it has a strong nucleus of work in this field as well as in women's rights, holding that 'the rights to the body, to sexuality and to equal opportunities between women and men, regardless of their sexual orientation, are human rights' (não te prives 2001).

In the history of the Portuguese LGBT movement, two years are particularly significant. The first was 1997, the year when the Gay and 
Lesbian Community Centre in Lisbon was inaugurated, under the responsibility of the International Gay and Lesbian Association (ILGA-Portugal). The year of the first homosexual pride celebration in the country (called 'Arraial Gay'16) and the first Gay and Lesbian Film Festival also both took place in Lisbon in 1997. The second year was 2000, when the First Homosexual Pride March was organized, attracting around 500 participants. Also that year, the Gay Fest was jointly organized by the main homosexual groups, and thus ceased to be the exclusive responsibility of ILGA-Portugal, as had been the case until then. In addition to the customary Lisbon Mayor's communiqué, the Arraial 2000 began with reflections by the leaders of the LGBT organizations involved upon the importance of that day in the process of sexual emancipation, stressing the need to extend the struggle to the interior of the country, to those who are isolated, and to the whole of society.

\section{Constructing Networks with Other Discriminated Groups}

The year 2000 has been a year of great public visibility for the Portuguese LGBT movement. What is its ideological framework and who are its allies in different sectors of civil society? One response will answer both questions: the democratic left. ${ }^{17}$ However, closer analysis of the practices and discourse of the LGBT movement reveals that the identification of strategies and of potential allies is a more complex matter.

On 30 June 2000, a debate was held at the headquarters of ILGAPortugal about the various forms of struggle used by the LGBT movement. It involved representatives of the GTH, the Sappho Club and ILGA itself, and was an occasion for the examination of the aims, strategies and alliances of the movement. From the point of view of the associations present, the main objectives and strategies were: intervention in schools and amongst the medical profession, through the dissemination of information, participation in debates, and so on.; continuation of the struggle against homophobia, by writing communiqués and letters to the press, etc.; the creation of visibility (through street demonstrations, and so on); and the decentralization of the movement itself. Favourite allies in the struggle for sexual emancipation included human rights groups, women's groups and the so-called 'friendly straights', which include some journalists and students. ${ }^{18}$

The manifesto published by the movement during the 2000 March identified new interlocutors in civil society:

Because we are discriminated against, we cannot abandon the struggle for human rights, for a society in which sexual orientation, gender identity, the colour of the skin, handicap, nationality, 
economic means and sex are not a pretext for exclusion or violence against any human being ... a multicultural country based upon solidarity. We want the legalization of immigrants that live and work in Portugal. We want more sympathetic asylum laws. ... We want social rights at work and in the healthcare system. We want the end of employment insecurity.... We are against violence to women, particularly handicapped women. We want the right to decide about our own bodies.

Among the different organizations subscribing to this manifesto were the Portuguese Handicapped Association, the Anti-Racism Network, SOS-Racism and the General Union of Workers (UGT). Therefore, in addition to the expected alliance with the feminist movement, shown by the presence of organizations like the Democratic Women's Movement (MDM) and the Alternative and Response Women's Union (UMAR), the Portuguese LGBT movement has been able to muster support amongst workers, ethnic minorities and handicapped people, by means of platforms of common interest and understanding.

The concerns which have marked the development of the Portuguese feminist movement have intersected with many of the issues of the LGBT movement, and thus their struggles have converged at different moments. The system of oppression, patriarchy, is of course common to both, in that it imposes stereotypical models of man and woman and assigns them predetermined social roles. ${ }^{19}$ Two of the many different partnerships may be cited. During the Women's World March, in October 2000, different lesbian organizations promoted the active participation of the community, and the final document, signed by all associations involved in the event, contained special demands for lesbians. More recently, the Homosexual Working Group issued a public complaint about a television programme called Mulher Não Entra (Women Not Allowed), which it called 'misogynist, macho and sexist' for reducing women to 'mere objects of male desire, despising them and diminishing their identities and their social, cultural and political role' (Público 21 April 2001). This public defence of women's dignity by an LGBT organization, regardless of their sexual orientation, would seem to illustrate clearly the similarities between the LGBT and feminist movements.

Another old alliance has been with groups campaigning around AIDS, particularly Abraço, an association which later came to head the LGBT movement in Portugal (Santos 2002). Indeed, the first president of ILGAPortugal, Gonçalo Diniz, began his work at Abraço, deciding some years later to found the group which has become the largest Portuguese lesbigay organization. Since 1997, ILGA has organized an annual March in 
Memory of and Solidarity with Victims of HIV-AIDS. As regards the first march, held on 4 May 1997, Almeida (1997: 98) wrote:

Never have so many people been mobilized to take part in street demonstrations about sexual politics, except for the issue of abortion. ... Everyone knows that the struggle against AIDS is not and never has been a 'normal' movement of solidarity with victims or a request for funds for healthcare. It has never been just this. It has always been (particularly in this country) a catalyst, an opportunity and a motivation for the assertion of citizenship and sexual politics and lifestyles.

Political allies, operating under banners not always directly connected to the homosexual cause, are mostly found amongst parties of the left. Thus, in 1997, the Socialist Youth proposed a bill aimed at legalizing commonlaw partnerships between homosexuals. This was supported by the Green Party, but aroused the opposition of right-wing parties, seconded by the Catholic Church. Since 1999, LGBT rights have been particularly defended by the recently formed Left Bloc (Bloco de Esquerda), whose party leaders participated in the First Gay Pride March, in Lisbon in 2000. Indeed, since its formation, the Left Bloc has included on its political agenda the struggle against discrimination due to sexual orientation, presumably as a result of the existence of the Homosexual Working Group within the Revolutionary Socialist Party, one of the members of the Left Bloc. In March 2001, left-wing parties, namely the Portuguese Communist Party, the Greens, the Left Bloc and the Socialist Party, joined forces and managed to get the bill on common-law partnerships between homosexuals approved.

The relationship between the homosexual movement and the left has emerged from a common ideology based on the defence of freedom and the right to difference, essentially a struggle against all forms of oppression and exploitation. As Vitorino argues:

to support left-wing politics requires the courage to fight for all policies that are just, even the most complicated, and to break with all institutionalized injustices because we are fighting for a profound change in the unjust society in which we live. ... The LGBT movement is therefore as subversive of the present order as the ideas of the left. The emancipation of all the oppressed, including LGBT individuals, is the Left's cause (1999: 6).

This linking of the Portuguese LGBT movement with other associations or social movements is consistent with the new social movements of the South, particularly in Latin America, where the creation of networks 
between movements is common (Santos 1995b: 226). In Mexico, for example, the 1968 student uprisings have been identified as the precursor of LGBT liberation in that country, as it was the student movement that first introduced onto the political agenda demands relating to sexual autonomy from the government and the family. When the LBGT movement emerged in Mexico in 1978, it was characterized by its solidarity with other socially oppressed groups, such as prisoners, workers, and peasants. These connections later attracted the support of the feminist movement and intellectuals (Mejía 2000: 49-50). In Brazil, too, in 1978, the first LGBT organization of the country, called SOMOS: Group for Homosexual Assertion, became actively involved in struggles against racism and misogyny (Green 2000: 59ff.). More recently, the document prepared for the 10th National Plenary Meeting of the Brazilian labour federation CUT, held from 4 to 7 December 2001 in São Paulo, included a statement by the secretariat of social policy recommending the strengthening of:

trade union action oriented towards discussion, and the training, organization and mobilization of workers, in order to raise their awareness about homosexual rights and promote respect for different sexual orientations, as well as [the establishment of] partnerships with homosexual organizations, in order to achieve unity of action (CUT 2001: 35).

\section{ALTERNATIVE OR GLOBALIZED EMANCIPATIONS?}

The Portuguese LGBT movement is constructed between two different poles, just as happens internationally. ${ }^{20}$ On the one hand, there is the gay subculture, or the so-called 'pink industry', involving the consumption of homoerotic products manufactured and diffused through the globalization of supply and demand markets (for example, night entertainment, saunas and tourism). ${ }^{21}$ On the other, there is the political movement, which organizes campaigns to end discrimination, promote diversity and defend the right to difference and to the body, among other issues. This fight against discrimination is frequently linked to the struggles of other socially oppressed groups. An example of this is the launch of the project 'Office against Discrimination', in June 1999, proposed by Opus Gay and supported by the Portuguese Deaf Association, amongst others.

Between the two poles, public demonstrations of the LGBT community, on occasions such as the marches, fairs, or film festivals, overflow with symbols which, though globally commercialized, are indissociable from the struggle against discrimination. 
How can we thus evaluate the emancipatory potential of this movement with some measure of reliability, dissolved as it is in spaces of consumption and leisure and at the same time involved in struggles for the recognition of rights? In the final part of this essay, I attempt to reply to this question by discussing two key ideas:

(a) within the counterhegemony itself, sexual emancipation, as proposed by the international LGBT movement, is an alternative;

(b) the Portuguese LGBT movement presents socio-historical specificities which distinguish it from the globalized LGBT movement.

Let us first consider the concept of emancipation. The idea of emancipation presupposes the existence of unequal power relations, since, if power were not exercised in an exclusionary way, there would be no need to fight for equal opportunities and rights, for the right to difference or for inclusion. In other words, inequality and exclusion create the necessary conditions (subjection and exploitation) for the emergence of the will for emancipation. This view of sexual emancipation is based on the understanding that 'emancipatory relationships develop within relationships of power, not as the automatic outcome of any essential contradiction, but as created and creative outcomes of created and creative contradictions' (Santos 1995a: 409). This is to say, rather than seek some essence of emancipation, it is necessary to identify paths, seeds, diverse forms and alternatives for the emancipation of individuals and for their empowerment in the struggle against exclusion. Above all, it is important to understand that there is not one but many forms of emancipation and domination. Just as hegemony has many facets, so resistance requires multiple agencies and structures. As Weeks argues (1999: 47):

These new stories of the 'self', about sexuality and gender, are the context for the emergence of the sexual citizen, because these stories telling of exclusion, through gender, sexuality, race, bodily appearance or function, have as their corollary the demand for inclusion: for equal rights under the law, in politics, in economics, in social matters and in sexual matters.

Movements operating in the area of sexual orientation may, and frequently do, form alliances with other socially discriminated groups in the struggle for racial, political or sexual freedom (Diniz 2001). But individually, each one of these struggles has its specific ambit of oppression and resistance, according to which it defines its goals, strategies, allies and enemies. In the case of the LGBT movement, 
the struggle is waged against the imposition of the heterosexual model as a norm, which systematically silences and marginalizes thousands of gays, lesbians, transsexuals and bisexuals.

Using the map of structural spaces in contemporary societies proposed by Santos (2000), we can see that the struggle operates on many different fronts. In the domestic sphere, it involves fighting against a patriarchal ideology that constructs and nourishes historically dichotomized stereotypes of male and female roles, which is the basis for the subjection of homosexuality in relation to heterosexuality. The demand for recognition of common-law partnerships, formulated in 1997 by the Portuguese LGBT movement, is related to the need to democratize the domestic space, opening it up to alternative family models.

In the space of production, there is a need to prevent dismissals or the blocking of career advancement because of sexual orientation; a good example of this are the conversations begun in 1999 between the Homosexual Platform (consisting of Opus Gay, ILGA-Portugal, the Women's Group, GTH and the Sappho Club) and the General Confederation of Portuguese Workers (CGTP), the General Union of Workers (UGT) and the Unitary Workers Front, in order to ensure the protection of workers who may be discriminated against because of their sexual orientation. ${ }^{22}$

As regards the market, there is a need to promote spaces for LGBT entertainment, beyond the promotion of the pink industry, and for the diffusion of LGBT symbols such as the pins showing an inverted triangle or rainbow coloured flags. Indeed, this is the only space where awareness of oppression sometimes gives way before the pressure of consumption and mass culture. It should be stressed that the consumption of LGBT products may also be a way of achieving visibility (Bell and Binnie 2000). Therefore, the development of the LGBT market may be a way of deepening political consciousness of oppression and discrimination, without necessarily resulting in alienation from these issues. This is one of the alternative aspects of sexual emancipation within the wider context of counterhegemonic struggle.

Within the community, it involves investing in the maximization of identity and in its legitimation, going against the dominant JudaeoChristian morality by resisting notions of sin and guilt, and exposing homophobic attitudes amongst the clergy, politicians, and civil society.

The space of citizenship constitutes the legal arena par excellence, where the struggle against discrimination and for legal protection take place. This has been the space privileged by the Portuguese LGBT movement up to now, culminating in March 2001 with parliamentary approval of common-law partnerships between homosexuals. 
Finally, there is what Santos calls the worldplace (1995a: 417), where the epistomological form of global culture, human rights and global models of homosexuality are valorized; it is at this level that international LGBT organizations (such as ILGA-Europe, ILGA-World, International Gay and Lesbian Human Rights Commission, and so on) tacitly or explicitly define their symbolic resources and political strategies.

In this global process for sexual emancipation, the main allies have historically been the feminist movement and the black movement: the first because it is the oldest and best organized of the social movements against sexual oppression, and the second because it brings together a group of people who have always been deprived of access to the most basic rights in democracy. In the words of Hugo (1998), a GTH activist, racism and homophobia are two sides of the same coin:

Gays, lesbians, bisexuals and transsexuals continue to be segregated for challenging the bourgeois model of the family, necessary for the survival of capitalism for the reproduction of the work force; ethnic minorities continue to be exploited as cheap labour with no rights by that same bourgeoisie. In fact, we are all excluded and we have common enemies: the state, which does not recognize our rights, and the extreme right, which preaches against ethnic minorities as much as against homosexuals...

However, despite the collaboration of the three movements (LGBT, feminists and ethnic minorities), the participation of gays and lesbians in feminist and anti-racist organizations has not always been peaceful. In truth, many Portuguese lesbians have accused the feminist movement of using them to fill the rows of the struggle against discrimination at work or for the right to abortion, and sidelining other demands more directly related to the lesbian condition (GM, 1999: 7). In Portuguese lesbigay organizations, there is also the perception that there is a great deal of homophobia amongst ethnic minorities, just as there may be racism within the LGBT community (Hugo, 1998: 6). However, if we compare the LGBT movement with, firstly, the feminist one, and, secondly, with the anti-racist one, it would seem that there is a stronger connection between the homosexual and anti-racist struggles, proved, for example, by the constant presence of the association SOS-Racism at all the Gay Parades held in the country. However, recent initiatives on the part of women's organizations, such as the Women's World March, represent a qualitative leap in the defence of a set of demands shared by Portuguese feminists and lesbians. The participation of feminists in debates organized by lesbigay associations has also increased, as has the joint organization of discussion panels on subjects relating to the body and to gender. 
To return to the previously mentioned key notion that, within the counterhegemony itself, the sexual emancipation proposed by the international LGBT movement is an alternative, we can see that its difference resides particularly in the use made of tools supplied by hegemonic globalization (such as the press and internet) and in the maximization of the 'pink' industry and trade as a way of making visible a minority movement. This has been the strategy adopted mainly by LGBT movements in core countries such as the United Kingdom and the United States.

The second key notion has to do with the idiosyncrasies of the Portuguese homosexual movement. If we remember that for almost half a century, Portugal was under a dictatorial regime, which even prohibited the importation of consumer products like Coca Cola, it is easy to understand that the LGBT movement in Portugal, which has only manifested its presence publicly since the 1990s, does not have a wide range of homoerotic products for consumption, since these require a developed market. In truth, the Portuguese pink market, as well as being a very recent phenomenon, is restricted to a few entertainment places (bars, discotheques and saunas, most of which are situated in Lisbon), a bookshop, a hotel, a travel agency, and services supplied by the associations. In addition to circumstances imposed by this recent political past, the Portuguese LGBT movement itself is strongly influenced by the oldest homosexual organization in the country, the Homosexual Working Group (GTH) of the Revolutionary Socialist Party. The GTH, which has been operating since 1991, supports an ideology of liberation traditionally associated with the left, defending racial, sexual and gender equality, and this is reflected in all their public interventions (protests, marches, media interviews, and so on). In an interview given in 1999, Sérgio Vitorino, president of the GTH, stated, on the subject of rightwing homosexual organizations:

I think these right-wing movements are wrong, and are contradictory, because a right-wing homosexual movement is against the homosexual movement; in my opinion, it defends ideas that prevent us from achieving emancipation. They may be in perfect agreement with us as regards a series of legal discriminations, but they will not agree with us about the reduction of differences between genders, between masculine and feminine, about social inequality between men and women... when we speak of sexual freedom, when we demand sexual education in the schools... (Santos and Fontes 1999).

As Roberts argues, 'gay identity implies legal, civil and human rights, so that one can live one's homosexuality openly, enjoying the same rights of 
association and relationship as other men and women' (1995: 250). In other words, the right to choose and express a sexual orientation presupposes other rights and freedoms, which in turn lead to others.

The historical development of the LGBT movement shows that, although it began as a minority struggle, it has managed to transform itself into a large-scale expression of the claim to the right to the body and to sexual self-determination. In addition to obtaining rights and protection against discrimination, the Portuguese LGBT movement has frequently been an important ally in campaigns for the liberalization of abortion $^{23}$ and in struggles for the introduction of sexual education in schools, against domestic violence and for equality of gender. These alliances reveal the most emancipatory aspect of this fight, since the spectrum of claims encompasses both feminists and anti-racism groups. Thus, it is reasonable to assert that the LGBT cause actively seeks to enlarge human potential, freeing it from the prejudice and oppression that reduce it to a homogeneous model. It is, in sum, a struggle for diversity and, therefore, becomes most effective when it is undertaken by different groups in different circumstances of oppression and exploitation based on gender, race, ethnicity, class, status or sexual orientation. In the words of Serzedelo (2001), president of Opus Gay, 'this struggle is a struggle for democracy, a civic struggle, a moral struggle and a struggle for freedom: freedom for homosexuals and for heterosexuals, because where there are oppressed there are also oppressors'. Sexual emancipation thus bridges the gap with other forms of expansion of rights and liberties, empowering individuals to defend the right to difference without this being equivalent to inferiority. As D'Emilio argues, homosexuals have an important role to play in this respect:

Already excluded from families as most of us are, we have had to create, for our survival, networks of support that do not depend on the bonds of blood or the licence of the state, but that are freely chosen and nurtured. The building of an 'affectional community' must be as much a part of our political movement, as are campaigns for civil rights. In this way, we may prefigure the shape of personal relationships in a society grounded in equality and justice rather than exploitation and oppression, a society where autonomy and security do not preclude each other but coexist (1996: 270).

The need to collaborate with other exploited and oppressed groups, exposing injustices and inequalities, is in fact the goal of many LGBT organizations at the international level. In 1995, in the context of the vote for Proposition 187, which defended the denial of healthcare, education 
and social security to illegal immigrants in the United States of America, the National Gay and Lesbian Taskforce publicized its position:

The current battles against gay rights and immigrants pose a critical question about our country: will our democracy expand to provide rights to an increasingly diverse population, or will it contract to limit rights to only a few? Gay, lesbian, bisexual and transgendered communities must work in alliance with immigrant communities, communities of colour, and other groups to expose the broader agenda of the right, an agenda that attacks basic civil, human, labour, economic and reproductive rights. We must build a solid united front against intolerance to fight for a more inclusive democracy for all (Timoner 1995).

The joint struggle against oppression which discriminates on the basis of sex, ethnicity or sexual orientation is only one of the aspects which brings national LGBT organizations closer to other organizations at the international level. Work carried out collectively by Portuguese LGBT organizations and international NGOs is evident in the case of Amnesty International, for example. Not only did this organization participate in the Homosexual Pride March of 2001, it also set up an LGBT working group in the Portuguese section of Amnesty International, in July of that same year, similar to situations existing in other countries.

As regards the joint work of international and Portuguese LGBT associations, contacts have been made especially at the European level. From 4 to 8 October 2000, at the ILGA-Europe Conference in Bucharest, Romania, representatives from the Portuguese associations ILGAPortugal and Opus Gay were present. On that occasion, the 2002 ILGA-Europe Conference was scheduled, which will be hosted by Portugal. Branco (2000) has praised the participation of the Portuguese in international discussion forums, emphasizing the importance of the European framework as a source of power vis-à-vis the Portuguese government:

It is clearly important that Portuguese associations, in liaison with ILGA-Europe and other organizations, create pressure groups operating on the Portuguese state in order to achieve once and for all material equality; that is to say, so all of us can enjoy the same rights without any kind of discrimination, and so that we have a Community of People, a true Social Community.

In March 2000, Kurt Krickler, president of ILGA-Europe, was in Portugal and, in an interview with the magazine Korpus, mentioned the importance of the relationship between national and international 
LGBT organizations. According to him, the success of LGBT demands at the European level:

depends upon the strength of the organizations within each individual country, because, in Brussels, it is still the governments of the member states of the European Union that make decisions. If the various national organizations are not strong in their own countries, they will not manage to do anything in Brussels. The success of ILGA-Europe depends upon the success of its national counterparts (Sousa and Mailänder 2000).

The internet homepages of the different national LGBT associations represent another mechanism for the diffusion of activities organized by the LGBT movement in other countries or among international bodies such as the United Nations, the European Union or the European Parliament. ${ }^{24}$ This information is also available through Euroletter, the monthly electronic newsletter of ILGA-Europe, which publishes news about the development of the legal situation of gays, lesbians, bisexuals and transsexuals in Portugal (http://www.steff.suite.dk/eurolet.htm).

\section{CONCLUSION}

The groups and associations that make up the LGBT movement in Portugal have similar goals: the recognition of the civil rights of LGBT people and effective protection against all forms of exclusion. This is why I consider the LGBT struggle to be manifestly counterhegemonic, since exclusion is understood to be an arbitrary process, a result of the hegemonization of a truth discourse, which credibilizes the 'we' through the demonization of the 'other' (Santos 1999). But there are other reasons why it may be considered counterhegemonic, the most obvious of which is the fact that it asserts a sexual orientation that is not shared by the majority, nor defended by the dominant religious, social and political powers.

As I have tried to show, the strategies adopted by the LGBT movement in international and national contexts offer alternatives within the counterhegemonic current itself. In fact, in the struggle for sexual emancipation, the LGBT movement has managed to use the resources made available by globalization to disseminate its ideals, symbols and products.

However, despite the fact that the LBGT culture seems to benefit from the conditions created by the capitalist system, sexual politics operates within the context of a 'bottom-up' form of globalization. In other words, 
the work undertaken by national LGBT associations is characterized by the establishment of:

transnational coalitions of social groups victimized by the systems of inequality and exclusion, establishing networks between local, national and transnational associations as the most efficient way of struggling for equality and identity against the logic of capitalist globalization (Santos 1999: 59).

In order for the Portuguese LGBT movement to assume a posture of political and ideological rupture with the heterosexual hegemony, thus constituting an alternative for sexual emancipation, a list of important measures has been drawn up, some of which are already on the national LGBT agenda:

(a) the creation, development and strengthening of networks with other NGOs and social movements;

(b) the preparation of material for training workshops on equality aimed at the sectors of banking, real estate, journalism, law, etc.;

(c) awareness and social information campaigns;

(d) active defence of other subjects, such as sexual education in schools, the right to abortion and the end to domestic violence;

(e) public exposure of cases of discrimination due to sexual orientation;

(f) decentralization of actions in order to fight the isolation of LGBT citizens in rural parts of the country;

(g) assessment studies on the use and application of the law on commonlaw partnerships and its social impact.

As may be inferred, the LGBT agenda for the next decades must necessarily go beyond merely legal demands, since homophobic attitudes and discrimination do not change by decree.

Given the conservative political trends that have characterized Portuguese society in the last decades, and considering the enduring strength of the Catholic Church, one might wonder how the LGBT movement managed to achieve its (however small) victories, namely the legal approval of the common-law partnerships in 2001. In fact, as I have tried to stress throughout this essay, that represented one single moment of public recognition, and even so it had little impact on the everyday life of the non-heterosexual person, since that law is still awaiting implementation. Nevertheless, it was a highly celebrated achievement and one can only attempt to explain it by linking it to two main factors: on the one hand, the insertion of Portugal into a broader political framework, namely the EU and the Council of Europe, among other European institutions; on the other hand, the strategy of the LGBT 
movement towards a more diversified and inclusive visibility, which allows for networking and coalition building among several other social struggles. By doing so, the Portuguese LGBT movement found a way out of its inherited lack of social legitimation, and at the same time it mobilized more activists to defend LGBT rights as human rights.

For reasons given above, we may conclude that, while the globalized LGBT movement frequently makes use of the capitalist tools of industry and commerce in order to achieve greater social visibility, Portugal is the stage for an emancipatory and counterhegemonic LGBT movement which has not allied itself to the expansionist and predatory logic of the global gay market. On the contrary, the agenda of the Portuguese LGBT movement includes demands that reflect the need for transversal liberation and self-determination for the whole of society, permitting the creation of links between very diverse associations and movements. Thus, Portuguese LGBT associations have been distinguished by a discourse that actively defends human rights, and which is expressed in practice in the struggle towards a social system that values diversity, in which difference does not mean exclusion and in which the civic participation of gays, lesbians, bisexuals, transsexuals, ethnic minorities and women (the sectors of the population which have most suffered from discrimination in the past) is considered a factor for social, political and cultural enrichment.

\section{NOTES}

1. Since the concept 'homosexual' refers to a very restricted universe that does not correspond to the diversity of sexual orientations within the movement, throughout the text I will use the initials LGBT to refer to 'lesbian/gay/bisexual/transgender'.

2. Sérgio Vitorino, president of the Homosexual Working Group (Grupo de Trabalho Homossexual - GTH), claimed that 'the relationship between homosexuals is much more than just an economic and financial issue', arguing that common-law partnerships 'presuppose a family setting that a common economy does not alone imply' (Korpus 14).

3. It is important to remember that the conventional heterosexual model is a cultural product that has been skilfully constructed in order to serve the economic interests of the capitalist system. As Greenberg and Bystrin remind us, 'the resulting ideology of the family called for monogamy, linked sex inextricably with love and procreation, asserted the sexual innocence of children despite prolonged adolescence, and endorsed a sharp sexual division of labour' (1996: 88).

4. See, amongst others, LARG, 1996. Greenberg and Bystrin (1996) identify five factors that relate the advent of the capitalist order with the stigmatization of homosexuality: (a) the intensification of competitiveness at work; (b) the development of an ethos of self-restraint contrary to the expression of sexuality; (c) a sharper sexual division of labour; (d) the strengthening of the ideology of the family; (e) the medical interpretation of deviance.

5. A report on homosexuality in Portugal, carried out in 1998, gives some examples of stories with a less than happy ending. See Visão, 24-30 September 1998: 73. 
6. Recently posters could be seen on the streets of Chueca with the words 'Assert yourself, consume Gay!'

7. In the same vein, Quiroga (1997: 147) asserts: 'The consumers of capitalist sex are becoming isolated members of a tribal category where sexuality is commercialized in saunas, where the simulacrum of sex leads to alienation'.

8. For a similar phenomenon in the Colombian context, see Villegas and Uprimny (2002).

9. As Rodrigues asserts, 'as conflict and dissatisfaction are inherent to the whole of society, the formation of social movements does not depend upon this type of factors, but upon the material and human resources indispensable for the channelling of discontent and the pursuit of collective aims' (1995: 3-4).

10. Contrary to what is commonly supposed, particularly by outsiders, the revolution for democracy in 1974 did not entail an explosion of a strong workers' movement. In fact, as Estanque notes, Portugal witnessed the emergence of several social movements characterized by their heterogeneity, local dimension, fragmentation, high media visibility and ephemerality (see Estanque 1999).

11. In different contexts, other factors explain the absence of a strong tradition of social movements. In Colombia, for example, violence plays a central role. See Villegas and Uprimny (2002).

12. By 14 May 1998, the deadline for groups of citizens to register with the National Election Committee in order to be entitled to radio and TV spots during the campaign, eight groups had done so: three in favour of decriminalization and five against.

13. This manifesto was characterized by a strong political consciousness identified with the revolutionary left, and it appealed to all citizens to join the struggle against sexual repression, while demanding the introduction of sexual education in schools and the decriminalization of homosexual practice.

14. The 1970s was of course a period of homosexual liberation in the United States of America, which became the stage for a growing sexual diversity, increasingly more public and politicized, and the consolidation of homoerotic culture. It was during this decade that the American Psychiatric Association withdrew homosexuality from its list of mental illnesses, an important moment in the struggle against discrimination.

15. An example were the demonstrations in 1996 against the definition of the terms 'homosexuality' and 'lesbianism' supplied by the Dictionary of the Portuguese Language (Porto Editora), or, more recently, the inclusion of homosexuality in the National Classification of Disorders, published in the Diário da República (II ${ }^{a}$ Série), on 6 January 1999.

16. In June 1969, a group of police officers invaded the New York bar Stonewall Inn and beat up homosexuals who, for the first time, resisted, which led to a riot. This was the event that kindled the struggle for the homosexual cause in the United States, and since then, 28 June has been marked as the day for the celebration of gay pride worldwide, with marches, candlelit processions, festivals and shows promoting the LGBT movement.

17. On the relationship between the LGBT movements and the political left, see Green (2000). This author has studied the establishment of alliances between the Brazilian LGBT movement, on the one hand, and the trade unions and some sections of the left, on the other, and points out that this relationship was the result of a long process of negotiation that lasted for more than two decades.

18. It is interesting to explore the possibility of an alliance between homo- and heterosexuals within a society that includes all. This is the intention of 'Gay and Straight Alliances', groups of North American public school students, who have, since 1988, joined together to fight against all forms of homophobia (Roxo 2000: 10).

19. On this subject, Santos (1995b: 233) states: 'Obviously, sexual discrimination is not limited to the domestic sphere, nor is it always the result of the exercise of patriarchal power; but it sets, as it were, the matrix that legitimizes other forms of power that produce sexual discrimination'. 
20. Thanks to Joan Tronto for drawing my attention to this double aspect.

21. Concerning the growing commercialization of the annual LGBT pride celebrations in the US, Fox (2001) states: 'With the passing of years, the pride celebrations in the country have become more and more commercialized, and are now marketing opportunities for companies that wish to make a profit out of gay consumers'.

22. This dialogue is still in an experimental phase, with as yet no visible alterations on the agendas of these trade union confederations, a fact which has frequently been criticized by the LGBT movement in Portugal. According to Santos (1995b: 222), 'the exposure of new forms of oppression implies the denunciation of emancipatory theories and movements which have ignored, neglected, or even sanctioned them. This implies, therefore, a criticism of Marxism and of the traditional labour movement'.

23. In May 1998, in the newsletter Zona Livre, Fabíola Cardoso stated: 'I am a lesbian, but the issue of abortion concerns me directly. It concerns me because I am a woman, and because I would like to see the sun rise on the day when women reclaim some of the rights lost by their ancestors at a dark moment of history' (Zona Livre, 5).

24. The sites of ILGA-Portugal, Opus Gay and the Sappho Club are, respectively, http:// www.ilga-portugal.org/mapasite.html, http://www.opusgayassociation.com/, and http://www.clubesafo.com.

\section{REFERENCES}

Amnesty International (1997): Breaking the Silence. Human Rights Violations Based on Sexual Orientation, London: Amnesty International.

Almeida, M.V. de (1997): 'Pontapés na Bola Precizam-se', Visão, 22/05/1997, 98.

Bell, D. and J. Binnie (2000): 'The Love that Dares Not Forget Its Brand Name', in D. Bell and J. Binnie (eds.), The Sexual Citizen. Queer Politics and Beyond, Cambridge: Polity Press, pp.97-107.

Branco, L. (2000): 'A União Europeia Social e a Orientação Sexual', Korpus 11, p.21.

Central Única de Trabalhadores - CUT (1997): $6^{\circ}$ CONCUT: Resoluções e Registros, São Paulo: Coordenação Nacional do $6^{\circ}$ CONCUT.

Central Única de Trabalhadores - CUT (2001): $10^{a}$ CUT Plenária Nacional. Texto Base, 10, São Paulo: Coordenação Nacional da CUT.

D’Emilio, J. (1996): 'Capitalism and Gay Identity', in D. Morton (ed.), The Material Queer. A LesBiGay Cultural Studies Reader, Oxford: Westview Press, pp.263-71.

Diniz, G. (2001): 'Um Movimento Aberto', newsletter Sem Medos! 9, p.19.

Estanque, E. (1999): 'Acção Colectiva, Comunidade e Movimentos Sociais', Revista Crítica de Ciências Sociais 55, pp.85-111.

Ferreira, V. (1981): 'Mulheres, Família e Trabalho Doméstico no Capitalismo', Revista Crítica de Ciências Sociais 6, pp.47-86.

Foucault, M. (1994): A História da Sexualidade - A Vontade de Saber, Lisbon: Relógio D’Água.

Fox, C. (2001): 'We're Here, We're Queer, We Drink Coors Beer', The Rocky Mountain Bullhorn Online, http://www.rockymountainbullhorn.com/PrideFest.html, June 2001.

França, L. (ed.) (1993): Portugal, Valores Europeus, Identidade Cultural, Lisbon: Instituto de Estudos para o Desenvolvimento.

Green, J.N. (2000): 'Desire and Militancy: Lesbians, Gays and the Brazilian Workers Party', in P. Drucker (ed.), Different Rainbows, London: Gay Men's Press, pp.57-70.

Greenberg, D. and M.H. Bystryn (1996): 'Capitalism, Bureaucracy, Homosexuality', in S. Seidman (ed.), Queer Theory/Sociology, Oxford: Blackwell, pp.83-110.

GM - Grupo de Mulheres (1999): 'Feminismo e Lesbianismo em Portugal: Uma Luta à Parte?', Sem Medos! 4, p.7.

GTH - Grupo de Trabalho Homossexual (1991): Manifesto de Fundação do Grupo de Trabalho Homossexual do Partido Socialista Revolucionário, Lisbon: GTH/PSR. 
Hawkes, G. (1996): A Sociology of Sex and Sexuality, Buckingham: Open University Press. Hugo, (1998): 'As moedas têm duas faces', Sem Medos!, 2, 6.

Joaquim, T. (1998): 'Social Citizenship and Motherhood', in V. Ferreira, T. Tavares and S. Portugal (eds.), Shifting Bonds, Shifting Bounds. Women, Mobility and Citizenship in Europe, Oeiras: Celta, pp.77-84.

LARG - Los Angeles Research Group (1996): 'Material Oppression', in D. Morton (ed.), The Material Queer. A LesBiGay Cultural Studies Reader, Oxford: Westview Press, pp. $349-51$.

Mejía, M. (2000): 'Mexican Pink', in P. Drucker (ed.), Different Rainbows, London: Gay Men's Press, pp.43-56.

Moreira, V. (1998): 'Lições do Primeiro Referendo', Público, 30/06/1998, 10.

Mott, L. (1987): Inquisição e Homossexualidade, I Congresso Luso-Brasileiro sobre Inquisição, Lisbon: Universitária Editora.

Müller, U. (1998): 'The Micropolitics of Gender Difference in Family Life', in V. Ferreira, T. Tavares and S. Portugal (eds.), Shifting Bonds, Shifting Bounds. Women, Mobility and Citizenship in Europe, Oeiras: Celta, pp.329-44.

não te prives (2002): Manifesto. (mimeo). Available upon request to naoteprives@ yahoo.com

Osório, C. (2002): 'Poder político e protagonismo feminino', in B.S. Santos (ed.), Democratizar a Democracia. Os Caminhos da Democracia Participativa, Rio de Janeiro: Civilização Brasileira, pp.419-51.

Pais, J.M. (ed.) (1998): Gerações e Valores na Sociedade Portuguesa Contemporânea, Lisbon: Secretaria de Estado da Juventude.

Praça, A. (1998): 'Cónego Melo Apelo ao Voto', Público, 29 June 1998, 8.

QUEERS, E-mail sent to author in August 2000.

Quiroga, J. (1997): ‘Homosexualities in the Tropic of Revolution', in D. Balderston and D.J. Guy (eds.), Sex and Sexuality in Latin America, New York: New York University Press, pp.133-51.

Rich, A. (1993): 'Compulsory Heterosexuality and Lesbian Existence', in H. Abelove, M.A. Barale and D.M. Halperin (eds.), The Lesbian and Gay Studies Reader, London: Routledge, pp.227-54.

Richards, J. (1990): Sexo, Desvio e Danação. As Minorias na Idade Média, Rio de Janeiro: Jorge Zahar Editor.

Roberts, M.W. (1995): 'Emergence of Gay Identity and Gay Social Movements in Developing Countries: The AIDS Crisis as Catalyst', Alternatives 20, pp.243-64.

Rodrigues, E. (1995): 'Os Novos Movimentos Sociais e o Associativismo Ambientalista em Portugal', Oficina do CES, p.60.

Rodrigues, L.P. (1994): ‘Uniões de Facto são Marginais', Expresso, 26/07/1994, 19.

Rodrigues, R. (2000): ‘Numa Europa Social os Trabalhadores Não São Só Trabalhadores', paper presented at the Alternative Summit, Lisbon, 24 March 2000.

Rodriguez, E. (2000): 'A peseta rosa', Sem Medos! 6, pp.8-9.

Rosebloom, R. (1996): Unspoken Rules, London: Cassell.

Roxo, J. (2000): ‘Alianças Gay-Hetero Contra a Homofobia', Sem Medos! 6, p.10.

Santos, A.C. and F. Fontes (1999): 'Descobrindo o Arco-Íris: Identidades Homossexuais em Portugal', BA thesis in Sociology, Faculty of Economics, University of Coimbra.

Santos, A.C. (2002): 'Sexualidades politizadas: o activismo nas áreas da sida e da homossexualidade em Portugal', Cadernos de Saúde Pública. Ministério da Saúde, Brasil. vol. 18, n. 3 (mai-jun 2002): 595-611.

Santos, B. de S. (1992): O Estado e a Sociedade em Portugal (1974-1988), Oporto: Afrontamento.

Santos, B. de S. (1995a): Towards a New Common Sense. Law, Science and Politics in the Paradigmatic Transition, London: Routledge.

Santos, B. de S. (1995b): Pela Mão de Alice. O Social e o Político na Pós-Modernidade, Oporto: Afrontamento. 
Santos, B. de S. (1999): 'A Construção Multicultural da Igualdade e da Diferença', Oficina do CES, p.135.

Santos, B. de S. (2000): A Crítica da Razão Indolente, Oporto: Afrontamento.

Santos, B. de S. (2001): A Cor do Tempo Quando Foge, Oporto: Afrontamento.

Seidman, S. (1997): Difference Troubles. Queering Social Theory and Sexual Politics, Cambridge: Cambridge University Press.

Serzedelo, A. and J.M. Cunha (2001): 'Direitos Humanos e Cidadania', http://www. opusgayassociation.com, April 2001.

Sousa, I. and M. Mailänder (2000): 'Entrevista com o Presidente da ILGA-Europe’, Korpus 11, pp. $20-2$.

Stein, A. and K. Plummer (1996): “"I Can’t Even Think Straight”: “Queer” Theory and the Missing Sexual revolution in Sociology', in S. Seidman (ed.), Queer Theory/Sociology, Oxford: Blackwell, pp.129-44.

Tatchell, P. (2001): paper presented at the conference Encontro Internacional Lutar Amando, Amar Lutando. Lisbon: GTH, 12-13 May 2001.

Timoner, R. (1995): 'The Costs of Scapegoating: Anti-Immigrant Backlash', National Gay and Lesbian Taskforce. http://www.ngltf.org/library/archive.cfm, Nov. 1999.

Uprimny, R. and M.G. Villegas (2002): 'Corte Constitucional y Emancipación Social en Colombia', in B.S. Santos (ed.), Democratizar a Democracia. Os Caminhos da Democracia Participativa, Rio de Janeiro: Civilização Brasileira, pp.297-339.

Vala, J., M.V. Cabral and A. Ramos (eds.) (2003): Valores Sociais: Mudanças e Contrastes em Portugal e na Europa, Lisbon: Imprensa de Ciências Sociais.

Vitorino, S. (1999): ‘A Homossexualidade e a Esquerda - Que Esquerda?’, Sem Medos!, p.4. Vitorino, S. (2000): Intervention in the Debate Formas de Luta do Movimento LGBT, Lisbon: ILGA-Portugal.

Weeks, J. (1999): 'The Sexual Citizen', in M. Featherstone (ed.), Love and Eroticism, London: Sage, pp.35-52. 